\title{
IAMJ
}

INTERNATIONAL

AYURVEDIC

MEDICAL JOURNAL

\section{ROLE OF JALOUAKA AVACHRANA AND DHOOPANA KARMA IN VRANASHOPHA(CELLULITIS): A CASE STUDY}

\author{
Sejal. A. Gamit
}

Assistant Professor, Shalya Tantra Dept. Shree Swaminarayan Ayurvedic College Kalol, Gandhinagar, Gujarat, India

Corresponding Author: dr.sejalgamit@gmail.com

https://doi.org/10.46607/iamj5109092021

(Published Online: September 2021)

Open Access

(C) International Ayurvedic Medical Journal, India 2021

Article Received: 20/08//2021 - Peer Reviewed: 02/09/2021 - Accepted for Publication: 03/09/2021

\section{Check for updates}

\section{ABSTRACT}

Cellulitis is a common and sometimes painful bacterial skin infection.it may first appear as a red, swollen area that feels hot and tender to the touch. The redness and swelling can spread quickly.it most often affects the skin of the lower legs, although the infection can occur anywhere on a person's body or face. Cellulitis usually happens on the surface of the skin, but it may also affect the tissues underneath. Vrana Shopha explained by Acharya Sushruta resemble inflammatory swelling, which appears red, swollen area that feels hot and tender to touch. Jalouka Avcharana and Dhoopana karma was the best therapy because of its safety and high efficacy in the management of Vrana Shopha.

Keywords: cellulitis, Vrana Shopha, Jalouka Avcharana Karma, Dhoopana Karma

\section{INTRODUCTION}

Acharya Sushruta Father of Indian surgery (shaly tantra) in which Surgical \& Para surgical techniques are described for the management of various diseases.
Acharya Sushruta has described the whole chapter on Vrana Shopha Which is mentioned in Sushruta Samhita sutrasthan ${ }^{1}$.in this chapter Acharya Sushruta 
was given detailed description of Vrana Shopha. According to the sign \& symptoms of Vrana Shopha it can be correlated with cellulitis. Vrana Shopha is the preliminary stage of nija Vrana.

Cellulitis is a common and sometimes painful bacterial skin infection.it may first appear as a red, swollen area that feels hot and tender to the touch. The redness and swelling can spread quickly.it most often affects the skin of the lower legs, although the infection can occur anywhere on a person's body or face. Cellulitis usually happens on the surface of the skin, but it may also affect the tissues underneath.

It can be superficial \&deep.it is common in diabetics, immunosuppressed people and old age. Commonly due to streptococcus pyogenic and another gram +ve organism. release streptokinase and hyaluronidase cause the spread of infection. Main sign symptoms swelling is diffuse \& spreading in nature, pain \&tenderness red shine area with stretched warm skin no edge, no pus, no fluctuation no limit ${ }^{2}$.

Jalouka Avcharana is mainly used for the treatment of Raktaja and Twak Roga (blood-related disorder or skin disorder) in children, old, aged person patients contraindicated for surgery ${ }^{3}$. the ayurvedic texts consider the primary cause of skin disease is Raktadusti and the patient get relief after letting out the vitiated blood. Rakta Mokshana is one among shodhana mentioned in kustha ${ }^{4}$.

Dhoopana is an inseparable part of therapeutics in this system Dhoopana is a method by which drugs of herbal, Herbo-mineral or animal origin are used, for fumigation to heal Vrana, Yonivyapad, Nasarogas, Gatradaurgandhyata disinfect Bheshajagara, vranagra, sutikagara kumaragara etc. and also, to sterilise Asavas and Aristas. since the Vedic period Homa-Havana and yagnya, sterilization of air by agnihotra, sterilization of house \& place around it by Dhoopana is going on traditionally ${ }^{5}$.

\section{Objective of Study}

To find out the efficacy of Jaluaka Avcharana and Dhoopanakarma in the management of Vrana Shopha (Cellulitis's)

\section{CASE REPORT}

A 72-year-old female patient visited Shree Swaminarayan Ayurvedic Hospital OPD in Shalya Tantra Department with complaints of inflammatory swelling, which appears red, swollen area at right leg which feels hot and tender to touch with ulcer formation and mild fluid collection at the affected site. Vrana Dhoopana was done twice a day with Jalouka Avcharana was done 5 times with an interval of three days that is, on days $1,5,9,13,17$ with internal medication.

Method of Jalouka Avcharana

Methodology

\section{Purva Karma}

Cleaning a site of varicose eczema before leech was applying. Then leech was put in Haridra mixed turmeric powder for purification of leech and then put in normal water.

\section{Pradhan karma}

Then Jaluaka was applying at the site of varicose eczema. While sucking the blood following signs appears in the body of the leech

a. Gradual distension in the central portion of the body.

b. Itching and burning sensation at the site of the bite.

c. Pulsations on the body of the leech may be visible. After application of Jaluaka Leech through its front end and covers the leech with wet cotton. Removal of Leech After 30- 45 minutes the leech is removed by itself, or by application of turmeric powder on the mouth of the leech.

\section{Paschal karma}

After removal of Jaluaka pt. dressing with Haridra powder Churna and bandage was applied. Vamana karma of leech was done.

\section{Dhoopana karma}

Aacharya Charaka and Sushruta has advised doing Dhoopana with Rakshoghna Dravyas ${ }^{6}$. Fumigation of the ulcer should be done by exposing the Affected part to the smoke coming out from the box of two earthen sources. By which exposing the Affected part to smoke, there will be relief of pain, cleanliness and 
mitigation of exudation. Fumigation Should be done with the powder of Guggulu, vidanga, Sarjarasa, Vacha, Gaurasarshapa added with lavana, Nimbapatra and ghrita. Fumigation should be done for ten nights, twice a day with Sarshapa, Nimbapatra Added with Ghrita. The process of fumigation to the wound should be done the exposing the Affected part through the smoke which comes out from the box of two earthen sources. Due to this smoke exposing to the Affected part to reducing the pain, surface cleanliness and mitigation of exudation. Fumigation of the ulcer encouraging granulation tissue formation relieved from pain, discharge and cleans ulcer.

Table 1: medicine, dose, duration, time

\begin{tabular}{|l|l|l|l|}
\hline Sr.no & Medicine name & Dose & duration \\
\hline 1. & Nimba Vati & 2/BD after meal & 15 days \\
\hline 2. & Punarnavadi Kwatha & 15ml/BD after the meal & 15 days \\
\hline
\end{tabular}

\section{RESULT}

In this case, improvement is seen in discolouration, accumulation of fluid, oedema and inflammation is relived with ulcer are healed. Jaluaka Avcharana and Dhoopana Karma were effective treatment modalities taken for the study were having local action. Nimba Vati and Punarnavadi Kwatha are also helpful for blood purification and help to get rid of excess fluid accumulated due to cellulitis.

\section{DISCUSSION}

Management of Vrana Shopha has been a great challenge since antiquity for surgeons throughout the world. Healing is a natural process but inhibited by many factors. The main goal or achievement of shodhana chikitsa is to alleviate these inhibitory factors. Finally at the end of shodhana chikitsa (purification). For Dhoopana karma (fumigation) using drugs have the quality to purify the Vrana Shopha by kills micro-organism when used in the form of smoke and keeps the area clean and fasten the healing process. Leech application has a peripheral vasodilator effect due to the presence of vasodilator constituent in the saliva which improves blood circulation and corrects "ischemia" around the wound, thus promotes wound healing. Leech applications have Anti-inflammatory action on nerves due to the presence of substance

$\mathrm{s}$ like Bdellins and Eglin's in the saliva which prevents leukocyte accumulation in the surrounding vessels, thus inhibits the release of inflammatory factors. Leech therapy is considered the most unique and effective method of bloodletting. It can be tried in all mankind including Females, Children, Old and Patients having poor threshold to pain. It drains impure blood, useful in Pitta dushti Rakta diseases, various skin disorders and all types of inflammatory conditions. In Sushruta samhita Chikitsasthana, chapters 12 and 16, Sushruta has advocated that bloodletting by Leech can be practised in all inflammatory, suppurative and painful conditions to relieve pain and inhibit suppuration.

\section{CONCLUSION}

Due to Vrana Dhoopana smoke exposing to the Affected part to reducing the pain, surface cleanliness and mitigation of exudation. Leech applications have Anti-inflammatory action on nerves due to the presence of substances like Bdellins and Eglin's in the saliva which prevents leukocyte accumulation in the surrounding vessels, thus inhibits the release of inflammatory factors. Punarnava acts as an antibacterial and anti-inflammatory agent. It is also considered one of swollen feet and ankle as it can eliminate excess fluid from the body through urination.

\section{REFERENCES}

1. Sushruta, Sushruta Samhita, with Nibandha Sangraha commentary by Dalhana and Nyaya Chandrika commentary by Gayadasa, foreword by Acharya Yadavji Trikamji. 8th edition. Varanasi: Chaukhamba Sanskrit Sansthan; 2014. Pp.81 
2. Swartz MN, Pasternack MS Principles and Practice of Infectious Diseases Cellulitis. Section of Cellulitis and subcutaneous tissue infections ( $\left.6^{\text {thedn }}\right)$. In: Mandell GL (ed.) Elsevier Churchill Livingstone, Philadelphia, 2005; 1178-1180.

3. Electrical A, Sawyer RT, Jones CP, Atkinson T. Isolation of thrombin inhibitor from the leech Hirudinea riamanillensis. Blood Coagul Fibrinolysis.,1991; 2: 83-9. [PubMed]

4. Sushruta, Sushruta Samhita, with Nibandha Sangraha commentary by Dalhana and Nyayachandrika commentary by Gayadasa, foreword by Acharya
Yadavji Trikamji. 8th edition. Varanasi: Chaukhamba Sanskrit Sansthan; 2005. Pp.824; p.443,446

5. Anant Kumar V, Shekokar, Kanchan M Borkar. To study the Efficacy of Ayurvedic Dhoopana for operation Theatre Sterilization. International Journal of Advanced Ayurveda, Yoga, Unani, Siddha and homoeopathy 2013;2(1):143-147

6. Sushruta Samhita of Maharshi Sushruta edited with Ayurveda tattva Sandipika by Kaviraj Ambika Dutta Shastri, Reprint 2012, Published in Chaukhambha Sanskrit Sansthan, Varanasi, Chikitsa Sthan 1/133, p16

\section{Before and After Treatment pictures}
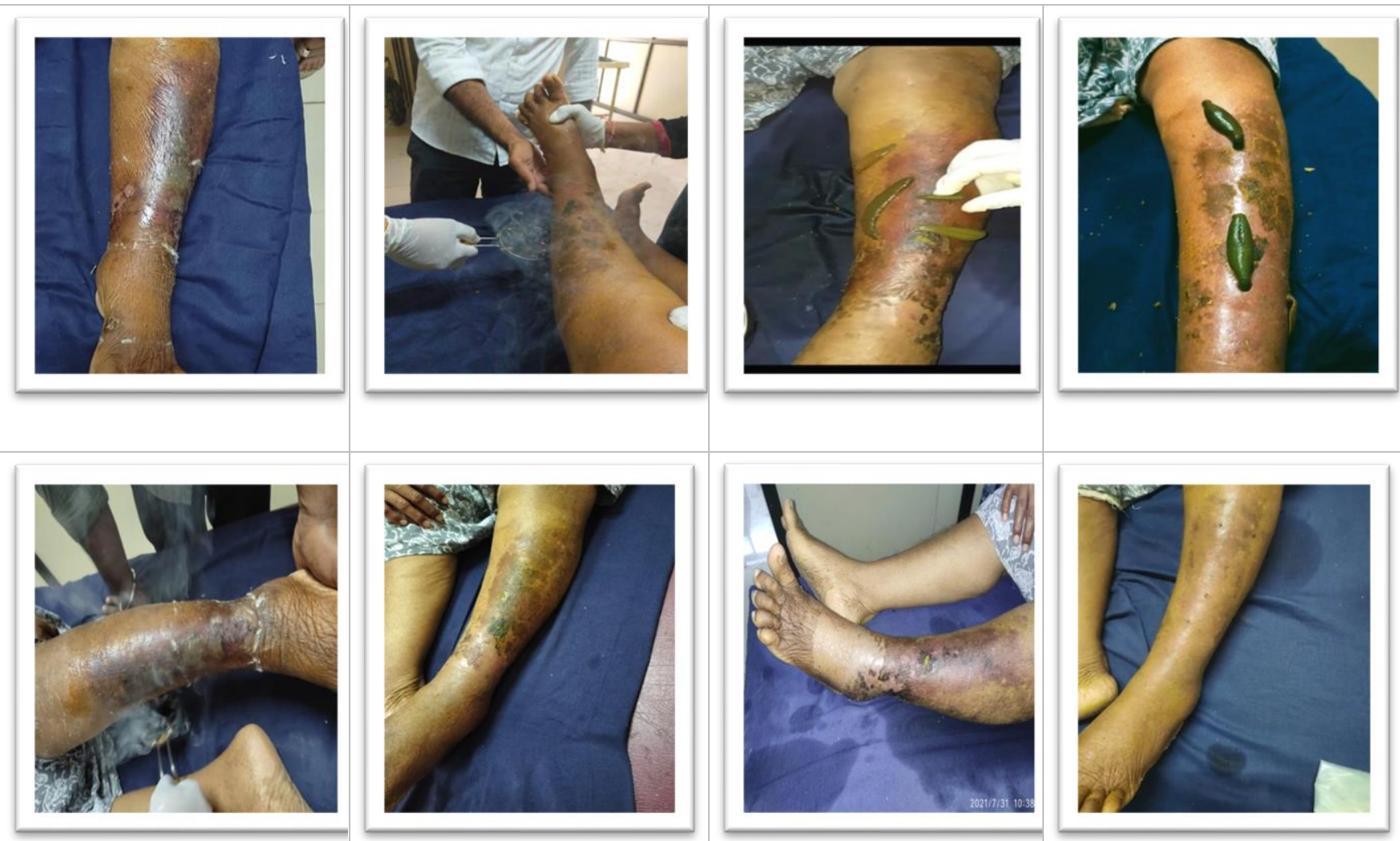

\section{Source of Support: Nil \\ Conflict of Interest: None Declared}

How to cite this URL: Sejal. A. Gamit: Role Of Jalouaka Avachrana And Dhoopana Karma In Vranashopha (Cellulitis): A Case Study. International Ayurvedic Medical Journal \{online\} 2021 \{cited September 2021\} Available from: http://www.iamj.in/posts/images/upload/2253_2256.pdf 